Journal of Product and brand management, 2002, Volume 11, issue 2, pp115-128

\title{
Options Theory and Options Thinking in Valuing Returns on \\ Brand Investments and Brand Extensions.
}

\section{Sam Dias and Lynette Ryals}

\begin{abstract}
Traditional methods of marketing evaluation may underestimate the true benefits from brand marketing unless opportunities for brand extension are included in the evaluation. However, valuing brand extension opportunities is not without difficulties. Traditional discounted cash flow (DCF) analysis may underestimate the value of brand extension, in particular the value of flexibility such as the ability to increase or decrease brand extension investment depending on future circumstances. We recommend an approach based on real options theory and demonstrate how this can be used both formally, to evaluate the contribution of marketing to the success of a brand extension, and informally, to influence the thinking of brand managers.
\end{abstract}

Key Words: Brand Extension, Marketing Effectiveness, Real Options

\section{Introduction}

The marketing budget is increasingly subjected to financial scrutiny. Accountability of marketers for their marketing spending and contribution to shareholder value creation is now a major issue (e.g. Srivastava, Shervani and Fahey, 1999). In fact, the evaluation of marketing has become a discipline in itself. One area of marketing spending that is coming under scrutiny is spending on brand development. Brands are increasingly regarded as company assets and, like tangible assets, require maintenance and development spending. How much investment a brand needs is an issue for marketing 
and brand managers. We argue that accepted methods of evaluating such spending are inadequate, in that they fail to recognise the option value of brand investment, which is only realised when a brand extension is launched. Using a real options framework that captures the value of brand extensions, we demonstrate that the returns on brand investment may be understated using traditional methods that primarily focus on the impact of brand marketing on generating incremental sales and ignore extension possibilities. This may lead to underinvestment in the brand, which may in turn undermine the brand's asset value.

A key objective of commercial organisations is the creation of shareholder value, a financial objective that impacts upon product and brand strategies to such an extent that a number of commentators have recently suggested that marketing should be measured by its contribution to the creation of shareholder value (Doyle, 2000; Srivastava, Shervani and Fahey, 1999; Varandarajan and Jayachandran, 1999; Srivastava, Shervani and Fahey, 1998). The emphasis on measuring marketing effectiveness is part of a wider picture in which marketing spending has increased as a proportion of overall costs, sometimes dramatically (Howell and Soucy, 1990). Increasing costs of advertising and promotion, as well as costly and sometimes high-risk e-commerce projects, have swelled marketing budgets and attracted closer scrutiny at a time when the emphasis on shareholder value creation has made companies focus not just on profits but on the risks as well as the returns of their investment in marketing and other projects.

At the same time, and for the same reasons, traditional brand management practices are coming under close scrutiny and their value-adding capabilities are under question (Knox and Maklan, 1998; Maklan and Knox, 1997). The practitioner literature suggests that the effectiveness of marketing campaigns is in fact often evaluated by estimating the incremental sales that are attributable to marketing activities. This is usually done with econometric modelling ${ }^{1}$ and/or where data permits with regional tests ${ }^{2}$ (Evelegh and

\footnotetext{
${ }^{1}$ Econometric modelling is a regression based technique which in this context isolates and quantifies key drivers of sales (eg price, distribution, economic growth, marketing activity, etc). An econometric model can be used to estimate the impact of marketing activity on incremental sales.
} 
Dias, 1998; Redhouse and Binet, 1996). These methods focus on short-term returns from incremental sales rather than longer-term value creation. Consequently, the financial returns through incremental sales do not always justify the marketing budget.

Intuitively, practitioners understand that measuring only incremental sales may give a misleading picture of brand marketing effectiveness and other studies have attempted to evaluate the manifold effects of marketing, for example by modelling the impact of marketing on distribution and/or inferring a causal relationship between brand marketing and lower price elasticity in addition to the impact on incremental sales (Holgate and Deykin, 2000; Cook et al., 1990). Where such modelling has been carried out, the apparent financial return may be considerably higher than the return generated from incremental sales alone.

Studying the impact of brand marketing on price elasticity and/or supply chain dependencies, however, does not deal with the further contribution that brand marketing makes, which is the potential for line and brand extensions. One could argue that, without investment in brand building, extension possibilities are limited. One survey of leading consumer product companies found that $95 \%$ of new product introductions were extensions and only 5\% were new brands (Aaker, 1991). This particular benefit of brand marketing has been recognised as an indication of marketing effectiveness.

\section{Underselling the brand}

We believe that traditional methods of marketing evaluation that are often employed by practitioners and which we have referred to above underestimate the true benefits from brand marketing unless extension opportunities are taken into account. However, putting a value on brand extension opportunities is not without difficulties. The usual approach is to use discounted cash flow (DCF) analysis. This involves forecasting the stream of future profits from each brand extension opportunity and then discounting them back to the present day. The discount rate reflects the degree of uncertainty about the future

\footnotetext{
${ }^{2}$ Regional tests can be used to analyse differences in sales of a brand between a test region where marketing is employed and a control region where there is no marketing.
} 
profit stream: the more uncertain, the higher the discount rate and, hence, the lower the net present value (NPV) of the cash flow. A simplified example of the DCF calculation used to value a future brand extension is shown as Table 1.

\section{Table 1: Valuing a future brand extension using DCF}

\begin{tabular}{|l|c|c|c|c|}
\hline & Year 1 & Year 2 & Year 3 & Year 4 \\
\hline Profit from brand extension & $\$ 10 \mathrm{~m}$ & $\$ 10 \mathrm{~m}$ & $\$ 10 \mathrm{~m}$ & $\$ 10 \mathrm{~m}$ \\
\hline Discount rate & $10 \%$ & $10 \%$ & $10 \%$ & $10 \%$ \\
\hline Discount factor & 0.91 & 0.83 & 0.75 & 0.68 \\
\hline Net present value (NPV) & $\$ 9.1 \mathrm{~m}$ & $\$ 8.3 \mathrm{~m}$ & $\$ 7.5 \mathrm{~m}$ & $\$ 6.8 \mathrm{~m}$ \\
\hline $\begin{array}{l}\text { Net present value of the } \\
\text { brand extension } \\
\text { opportunity }\end{array}$ & $\mathbf{\$ 3 1 . 7 m}$ & & & \\
\hline
\end{tabular}

In this simple example, profits from the brand extension arrive at the end of each year, starting from the end of next year. The brand extension is worth $\$ 10 \mathrm{~m}$ in profits each year for four years, a notional $\$ 40 \mathrm{~m}$. The discount rate used by the brand owners to discount future, more uncertain, profits is $10 \%$ per year so the apparent present value of the brand extension opportunity is a total of $\$ 31.7$ million.

Unfortunately, traditional discounted cash flow analysis may seriously underestimate the value of flexibility (Luehrman, 1998). For brand managers, flexibility such as the ability to increase or decrease brand extension investment depending on future circumstances might be very valuable indeed to enable them to respond to changes in market circumstances. We advocate a methodology based on real options theory because it can capture the value of flexibility. We will demonstrate that real options theory can evaluate the contribution of brand marketing to the success of a brand extension.

Real Options are a tool from the field of finance and project appraisal that enable managers to calculate by how much flexibility increases the value of an investment. We propose to borrow this tool from finance and apply it to brand marketing. Brand marketing and investment is linked to the concept of brand equity. For context, we provide a brief description of the concept of brand equity and the use and valuation of 
financial options. We then discuss real options and their application to brand marketing and go on to consider some of the managerial implications.

\section{What is Brand Equity?}

Many definitions of 'brand equity' exist. A recent definition of brand equity, for example, suggests that it encompasses three key elements of a brand: consumer association, brand strength and brand value (Feldwick, 1996). However, it is clear that the term is associated with, but distinguishable from, the valuation of a brand as an asset. Brand valuation exercises have often demonstrated that the value of brands as assets can be very substantial indeed (Haigh, 2000; Murphy, 1989). Brand marketing can be a powerful tool in creating and enhancing brand equity. Investing in brand equity through, for example, advertising campaigns, sponsorship etc opens up new opportunities for the brand which may include launching brand extensions, increasing a price premium and benefiting from market changes (for example, adapting the brand to changes in trends and fashions). The creation of such opportunities has financial value, but it is with regard to the first of these, brand extensions, that we shall concentrate in this paper. Our logicflow is as follows: if marketing enhances brand equity, then we expect that that brand equity will be leveraged, particularly in situations where brand extensions are planned.

If marketing enhances brand equity and facilitates brand extensions, why is the justification of spending on brand equity an issue for marketing managers? Unfortunately, when managers come under pressure to improve short-term performance, they sometimes not only stop brand extension activities but also reduce even the basic day-to-day marketing activity that serves to maintain the brand. This has the immediate effect of enhancing short-term profitability, even though it may undermine the longerterm equity of the brands. We argue that, if long-term brand equity was properly understood, the true financial impact of brand marketing would be much clearer. Investing in brand maintenance and in brand extensions builds future value. At the very least, on-going brand maintenance serves to keep a company's options open by keeping the brand alive and healthy. Investment in brand extensions may also offer the company flexibility in the future to extend the brand even further into new areas. To put a value on 
this flexibility, option theory is needed. The application of option theory is explained first by reference to its origins in financial options and then by the more recent application of the technique to investment in other assets ('real options').

\section{Financial Options}

A financial or securities option is the right to buy or sell an underlying financial asset.

In financial markets, options are tools that were originally employed to reduce the risk of adverse price movements. Buying an option bestows the right (but not the obligation) to buy or sell a stated property, security, or commodity at a given price within a specified time. Possession of the option protects the holder from the risk that the underlying asset changes in price, before the option holder is ready to buy or sell the underlying asset. There are two main types of financial options - 'calls' and 'puts'. A call option bestows the right to buy a security at a fixed price, whereas a put option bestows the right to sell a security at a fixed price. In this paper, we will focus on call options. The following hypothetical example will illustrate how a financial call option on a security works:

Today, shares of Company A are trading at $£ 10$. It is possible to purchase a one-year call option for $£ 3$. The owner of the option has the opportunity to purchase Company A shares for $£ 8$ (known as the exercise price) within 12 months time. If the buyer of the option decides to exercise the option today, the payoff would be $£ 2$. However, having spent $£ 3$ on buying the option, the buyer would be $£ 1$ out of pocket; $£ 1$ represents the premium he or she has paid for the flexibility to wait and exercise the option if and when the stock price increases within a year. The payoff diagram below illustrates the convex nature of the option and the value generated from owning it.

The net payoff to an investor is the amount by which the share price exceeds the exercise price, less the price paid for the option. If the share price falls below the exercise price, the investor is not obliged to exercise the option and therefore only the price paid for the 
option is lost. Essentially, the owner of the option limits downside risk, unlike a shareholder that bears the entire downside. A shareholder's payoff line is not convex - it is represented by the dotted line in the diagram.

\section{INSERT FIGURE 1}

\section{Real Options}

Just as financial options are the right to buy or sell financial assets, real options are the right to buy or sell real assets. Real options are particularly valuable in situations in which investment decisions can be deferred. Deferral has value not just because an organisation can earn interest on the capital it retains, but also because deferring a decision until the business situation clarifies reduces the uncertainty surrounding that decision (Buckley and Tse, 1996) and increases flexibility (Flatto, 1998). Where the investment cannot be deferred, the real option value and the NPV of a projected investment are identical (Luehrman, 1998). The value of deferral is the interest on the capital saved, plus the risk reduction. Real options can certainly be used to evaluate situations where the investor pays to learn about an uncertain quantity or technology (Copeland and Keenan, 1998) and to evaluate R \& D (Buckley and Tse, 1996). These are all situations that may arise where brand extensions are planned.

Real investment options are options embedded in real assets - for example the option to expand a project, abandon it, or defer investment. Advocates of real options suggest that the thinking behind financial options can be applied to real assets (Amram and Kulatilaka, 1999). Whereas financial options are associated with financial instruments, real options are employed when making real-life investment decisions. There is a vast body of literature illustrating and documenting the use of real options in various industries (e.g. Amram and Kulatilaka, 1999; Micalizzi, 1999; Smit, 1997; Smit, 1994; Paddock et al., 1988). We will illustrate with a simple example from the oil industry before moving on to discuss how real options are applicable in marketing. 
When a petroleum exploration firm searches for oil, a lease is paid on the land where the search is being conducted. The lease fee is usually paid to the land-holding government. Once oil is found, the firm has primarily three possible options available to it:

1. Start drilling and production

2. Sell the lease to another firm (effectively abandon the project)

3. Postpone drilling, but carry on paying the lease on the land

The decision rests on one key factor: the price of oil. If the price of oil is high and is above the minimum price that is required for production to be profitable, the most beneficial option would be to start production. Conversely, if the oil price is low, selling the lease or postponing production become the preferred options.

The real options solution in the low price scenario would be to postpone production until the price of oil increases and exceeds the minimum level required for profitable production. By continuing to pay the lease on the land, the firm is essentially buying a call option. The lease bestows the right to start drilling should the price of oil rise. If the price of oil does not increase, all that is lost is the amount spent on the lease - a small sum in comparison to having started drilling without a subsequent increase in the market price of oil. The cost of the lease is also a small sum relative to the potential gains that would result if the price of oil increased such that production was profitable.

Using a real options framework, the firm can price the option of extending the lease - i.e. estimate the maximum fee that should be paid for the right to start production. If the cost of the lease exceeds the maximum fee, the project should be abandoned. What usually happens in such a case is that cost of the lease is negotiated down. The government that owns the land usually has a team of advisors who employ real options models that can estimate the price of the lease. Hence, there can be agreement between government and oil producing firm with regard to the cost of the lease. The power of real options is that it offers a methodology that estimates the price of 'staying in the game' - in the case of the 
petroleum producing firm, this is the price paid to have the flexibility to drill when the oil price rises, without the obligation of having to drill should the price of oil not rise.

\section{INSERT FIGURE 2}

\section{Brand Equity as a Real Option}

The link between brand marketing and real options is conceptually straightforward. If we think of brand marketing as a vehicle that keeps the brand alive by building on brand equity, then by merely staying in the game, any extension opportunities that arise in the future can be exploited. Leveraging brand equity when exploring NPD avenues is likely to increase the likelihood of success of the venture. However, the financial value attributable to staying in the game is often overlooked when making marketing investment decisions. This is illustrated in the following hypothetical example:

A firm must decide whether to extend one of its brands into a new sector sometime in the near future. For the extension to be successful, the parent brand needs to be supported prior to the launch. An important assumption is being made here: the parent brand requires support in order to increase brand equity before the extension is launched. The extension will benefit from the increased equity of the parent brand. It is estimated that a minimum initial commitment of $£ 6 \mathrm{~m}$ of brand building advertising is required leading up to the launch. From past research on advertising effectiveness that has been conducted on the parent brand, it is estimated that $£ 6 \mathrm{~m}$ of parent brand advertising will generate earnings that have a net present value of $£ 5 \mathrm{~m}$ for the parent brand through incremental sales. The brand extension will also incur a sunk cost of a plant estimated at $£ 25 \mathrm{~m}$. Furthermore, the brand extension will require product specific advertising support of $£ 3 \mathrm{~m}$ at the time of launch. If the brand extension is successful, it is forecast to generate earnings that have a NPV of $£ 35 \mathrm{~m}$. Conversely, an unsuccessful brand extension will create earnings that have a NPV of $£ 10 \mathrm{~m}$. Assume further that success and failure are equally likely (probability of success or failure $=0.5$ ). Should the firm extend the brand? 
The traditional way to approach such a problem is to calculate the expected return from the venture. This is calculated as follows:

Costs $=6+25+3=\mathfrak{£ 3 4 m}$

$£ 34$ million is the total cost from parent brand advertising, plant building, and extension specific advertising.

Expected Earnings $=(5+35) \times 0.5+(5+10) \times 0.5=\mathfrak{\$ 2 7 . 5 m}$

The $£ 5 \mathrm{~m}$ that appears in both brackets refers to extra earnings from incremental sales generated from parent brand advertising. The $£ 35 \mathrm{~m}$ and $£ 10 \mathrm{~m}$ refer to predicted earnings from successful and unsuccessful extensions. Each outcome is equally likely and is therefore weighted by 0.5 .

Expected Profit from extension $=27.5-34=\mathbf{- £ 6 . 5 m}$

On the basis of the above calculation, the firm may decide not to proceed with the brand extension since the expected profit is negative. Moreover, the firm may even decide not to invest in brand advertising since the cost of advertising exceeds the incremental earnings from the parent brand. However, the expected profit calculation ignores the value of a real option that is present here. The above calculation implicitly assumes that the final decision to proceed or not has to be made now - i.e. there is no opportunity to 'wait and see'. The real options solution would be to invest in brand advertising and defer the decision to extend the brand until more information becomes available, maximising the benefit of flexibility. After a period of learning, the firm is in a position to go ahead with the brand extension if the likelihood of success is higher. Alternatively, the firm can abandon the whole idea if an unsuccessful extension is forecast - the only cost that would have been incurred is brand building advertising, but this would have been partially offset by earnings generated from sales of the parent brand. In effect, investing in the advertising campaign creates a call option - the right but not the 
obligation to proceed with an extension. The expected return calculation changes with the real options framework. We consider the pessimistic and optimistic cases separately:

\section{Optimistic Case}

Costs $=6+25+3=\mathfrak{£ 3 4 m}$

Expected Earnings $=5+35=£ 40 \mathrm{~m}$

Profit from extension $=£ 6 m$

\section{Pessimistic Case}

If the pessimistic case is forecast, the extension is not carried through. The plant is not built, the extension specific advertising cost is not incurred and income from the extension is not realised. All that is lost is the expenditure on parent brand advertising, which is partially offset by earnings from sales of the parent brand. We are essentially limiting our downside exposure.

Costs $=£ 6 m$

Earnings $=£ 5 \mathrm{~m}$

Profit from extension $=-\mathfrak{- 1 m}$

The results from the two scenarios are given equal weights and the expected profit calculated.

Expected profit (Probability weighted profit) $=6 \times 0.5+-1 \times 0.5=\mathfrak{\$ 2 . 5 m}$

What is happening here is that the investment in parent brand advertising creates an option that has value. The gap between the two expected return calculations arises because of the value of the option. The option can be exercised selectively - do so when it is to your advantage, but let it lapse when not. Therefore, we can effectively think of investing in parent brand advertising as analogous to buying a call option because it 
limits the firm from the downside exposure of the pessimistic case whilst allowing it to benefit from the optimistic case.

The payoff diagram for the hypothetical example is shown below:

\section{INSERT FIGURE 3}

Faced with an uncertain future, the owner of the brand can benefit from successful extension possibilities, whilst being insulated against unsuccessful ones (where the extension is not produced). This fundamental 'convexity', as depicted by the thick black line in the diagram, is what gives the investment in brand marketing (or the real option) financial value.

The hypothetical example above is something of a simplification of the decision making process. In reality, a firm may not be able so unambiguously to estimate the earnings and probabilities associated with successful and unsuccessful brand extensions. In fact, future brand extensions are not usually conceived of when brand investment decisions are made. Nevertheless, building on brand equity gives the brand options for the future even if the exact nature of the options is unknown. In a nutshell, investment in brand marketing keeps the option of future possibilities alive by building on brand equity, which can be leveraged when launching brand extensions.

\section{Successful Brand Extensions and Return on Investment}

If brand marketing investment creates brand equity and is analogous to buying a call option, it could be suggested that launching a brand without prior brand marketing investment (and hence no brand equity) is analogous to buying a financial asset outright. If so, the payoff from not investing in brand marketing would be as shown by the dotted line in the diagram below. The pay-off from investing in prior brand marketing would be as shown by the convex curve (thick shaded) line. The value created from the brand 
marketing option is the vertical distance between the two lines and is shown by the arrow. The vertical distance, or value created, is a (negative) function of earnings from the brand extension: as NPV of earnings from extension decreases, value created from the brand marketing option increases (and vice-versa). The relationship is formalised by the equation,

Value Created $(£ \mathrm{~m})=28-$ NPV Earnings from Extension, for earnings $<£ 28 \mathrm{~m}$

Value Created $(£ \mathrm{~m})=0$, for earnings $>£ 28 \mathrm{~m}$

The value of the option is over and above any manifold effects (price premium, distribution gains etc) benefiting the parent brand as a result of the brand marketing investment.

\section{INSERT FIGURE 4}

\section{Summary}

Where part of the value of an investment is that it provides a greater range of future options (greater flexibility) as well as a future stream of profits and cash flow, traditional discounted cash flow valuation techniques are known to understate the value of the investment (Luehrman, 1998). The more uncertain the future, the greater the value of an option (Flatto, 1998). Initially, option values were calculated using financial options (Scholes, 1997). Options theory was later extended to cover options on investment in real assets (real options).

We have applied options thinking to investments in brand equity and brand extensions and conclude that managers may underestimate the value of brand investment and brand extensions if they use traditional DCF tools to evaluate these strategies. The reason for this (as demonstrated in our example) is because the traditional NPV calculation did not capture the benefit of flexibility - in our example this refers to the flexibility to launch the 
brand extension if the optimistic scenario is forecast or abandon brand extension plans if the pessimistic case is forecast. Real options offer a way correctly to price the value of flexibility which occurs as a result of brand marketing investment.

If marketing managers are to evaluate the holistic impact of brand marketing then consideration of brand marketing as a real option is essential, in addition to the other benefits of brand marketing (eg incremental sales uplift, distribution gains, lower price elasticity etc). Furthermore, we would argue that, when estimating the contribution of brand marketing to shareholder value, the option value of the brand over and above the value at current use should be considered.

The mathematics of option pricing are not simple (in fact, the pioneers of financial option pricing theory won a Nobel Prize for their work), but real options are increasingly gaining ground as a way of understanding the value of a whole range of investments, not just brand marketing ones, and software products that calculate option values are widely available (Winston, 1996).

\section{Managerial Implications and recommendations}

The consequences of mispricing brand investments are that companies may underinvest in their key assets, their brands, particularly when times are tougher. Reducing brand investment may allow the company to reach its short-term targets but may undermine its ability to create value in the longer term. By demonstrating the true value of brand maintenance and brand extension marketing, real options allow marketing managers to defend their brand spending. In a climate where accountability for marketing spending is an increasing pressure, real options should be a tool that is used when marketing budgets are called to account. 
A second managerial implication is that understanding options may in itself change the way that brand managers develop strategies. For example, the more volatile the market, the more valuable the option because downside exposure is limited whilst the option can still benefit from the upside. Managers who understand options thinking will understand that, when times are highly uncertain, the best marketing strategies might be to make investments that create options, rather than to postpone all investment and possibly lose future opportunities altogether. Another aspect of options thinking is that options only have a value where there is flexibility in timing. Where there are no opportunities to scale investments up or down, the value calculated using DCF and calculated using options is the same (Luehrman, 1998). Brand managers using options thinking might be more appreciative of brand management strategies that build in greater flexibility. More flexible strategies might well enable organisations to react faster to both successes and failures. Where the brand manager has built in to his or her strategic plan the option to increase or decrease investment, he or she is more likely to be able to capitalise on a runaway success or scale down an unexpected underperformer.

There is also a recommendation for marketing managers about the use of real options, which is that real options can help managers decide what their marketing budgets should be. In finance, the price paid for a call option is the premium for flexibility - i.e. the amount paid to have the right to buy a share at a fixed price if and when the share price increases. Options theory contains a set of tools for the analyst to estimate the price that should be paid for the option. In other words, the value of flexibility can be estimated. In the marketing arena, if the marketing budget is analogous to the option price, in theory we should be able to apply tools developed in options theory to estimate the optimal size of a marketing budget. More research would be necessary to determine whether this should be the case.

\section{Are Options an option?}

Marketers have understood the importance of brand equity for a long time, particularly with regard to launching brand extensions. However, the language of real options has not 
been a part of marketing parlance. The benefit of using a real options framework is that it offers a methodology to estimate the contribution of brand marketing to the success of a brand extension.

Traditional evaluation methods concentrate on incremental sales and in some cases the effects of marketing on distribution gains and price elasticity are also taken into account. However, the return on investment from marketing endeavours is greatly increased if consideration of possible future outcomes and the value of flexibility are made. A real options based evaluation methodology would account for convex payoffs as in the example we have used.

We have argued that marketing budgets, when they are called to account, should make use of options theory to explain the true value-creating potential of investment in brands. Moreover, brand managers might actively explore flexible strategies that allow for investment in brand extensions to be scaled up or down if they are more aware of the value of these options.

The aim of this paper is to establish a framework of options thinking for brand marketers and to make a case that real options offer a promising tool for brand marketers to use in evaluating brand strategies. More work is required to evaluate the use of real options in marketing.

\section{References}

Aaker, D. (1991), Managing Brand Equity: Capitalizing on the Value of a Brand Name, Free Press, New York.

Amram, M. and Kulatilaka, N. (1999), Real Options, Harvard Business School Press, Boston. 
Buckley, A. and Tse, K. (1996), "Real Operating Options and Foreign Direct Investment: A Synthetic Approach”, European Management Journal, Vol.14 No. 3, pp. 304-314.

Cook, L., Cooper, C. and Jones, N. (1990), "How the chimps kept PG Tips brand leader through thirty five years of intense competition". Advertising Works, Vol. 6 pp. 3-25.

Copeland, T.E. and Keenan, P.T. (1998), "How much is flexibility worth?”, McKinsey Quarterly, Vol. 2, pp. 38-49.

Doyle, P. (2000), "Valuing Marketing's Contribution". European Management Journal, Vol. 18 No. 3, pp. $233-245$.

Evelegh, P. and Dias, S (1998), “Johnson's Clean \& Clear - Global advertising in a local market”. Advertising Works Vol. 10, pp. 363-400.

Feldwick, P. (1996), "Do we really need 'Brand Equity'?” Journal of Brand Management, Vol. 4. No 1, pp 9-28.

Flatto, J. (1998), “Using Real Options in Project Evaluation”. Resource, forthcoming.

Haigh, D. (2000), "Connecting Market Research with Shareholder Value", Journal of Brand Management, Vol. 7. No 3, pp 153-160.

Holgate, V and Deykin, A (2000), "Lurpak - Changing the nation's taste". Advertising Works Vol. 11, pp. 253-284.

Howell, R. A. and Soucy, S. A. (1990), “Customer profitability: as critical as product profitability". Management Accounting, Vol. 72. No 4, pp 43-47.

Knox, S.D. and Maklan, S. (1998), Competing on Value, Financial Times Management, London. 
Luehrman, T.A. (1998), "Investment Opportunities as Real Options: Getting Started on the Numbers", Harvard Business Review, Jul-Aug, pp. 51-67.

Maklan, S. and Knox, S.D. (1997), "Reinventing the brand: bridging the gap between customer and brand value", Journal of Product and Brand Management, Vol. 6 No.2, pp119-129.

Micalizzi, A. (1999), "The Flexibility of Discontinuing Product Development and Market Expansion: The Glaxo Wellcome Case", in Trigeorgis, L. (Ed), Real Options and Business Strategy: Applications to Decision Making, Risk Books, London.

Murphy, J. (Ed) (1989), Brand Valuation - Establishing a True and Fair View, Hutchinson, London.

Paddock, J., Siegel, D. and Smith, J. (1988), "Option valuation of claims on real assets: The case of offshore petroleum leases", Quarterly Journal of Economics, August, pp. 479-508.

Redhouse, D and Binet, L (1996), "Frizzell Insurance - When the Customer is not Always Right”. Advertising Works Vol. 9, pp. 107-136.

Smit, H.T.J. (1997), "Investment Analysis of Offshore Concessions in the Netherlands", Financial Management, Vol. 26 No. 2, pp. 5-17.

Smit, H.T.J., and Ankum, L.A. (1993), "A Real Options and Game-Theoretic Approach to Corporate Investment Strategy under Competition." Financial Management, Vol. 22 No. 3, pp. 241-250. 
Srivastava, R.K., Shervani, T.A. and Fahey, L. (1998), "Market-Based Assets and Shareholder Value: A Framework for Analysis”, Journal of Marketing, Vol. 62 No. 1, pp. 2-18.

Srivastava, R.K., Shervani, T.A. and Fahey, L. (1999), "Marketing, Business Processes, and Shareholder Value: An Organizationally Embedded View of Marketing Activities and the Discipline of Marketing", Journal of Marketing, Vol. 63 (Special Edition), pp. 168-179.

Varadarajan, P. R. and Jayachandran, S. (1999), "Marketing Strategy: An Assessment of the State of the Field and Outlook", Journal of the Academy of Marketing Science, Vol. 27 No. 2, pp. 120-143.

Winston, W. L. (1996), Simulation Modeling using @Risk, Duxbury, New York. 


\section{Authors' Biographies}

Sam Dias is a Managing Partner of Dataworks Analytics, a strategic marketing analysis consultancy that is part of the Publicis Group. Prior to this, he was Director of Brand Economics at Brand Finance plc.

Lynette Ryals is a lecturer in Marketing at Cranfield School of Management and Director of the Executive MBA Programme. She previously worked in the City and is a Fellow of UKSIP, the society for investment professionals.

\section{Acknowledgements}

We are grateful to Professor Simon Knox at Cranfield School of Management, David Haigh and Tim Heberden at Brand Finance plc, Mia Pandey at Interbrand and Thane Forbes at Intangible Business Ltd for their comments on earlier drafts of this paper. Thanks also to Dr Martha Amram and Professor Adrian Buckley for clarification of some key points in our argument. 